\title{
Changes in gonadotrophin secretion and ovarian antral follicular activity in seasonally breeding sheep throughout the year
}

\author{
K. P. McNatty, N. L. Hudson, K. M. Henderson, S. Lun, D. A. Heath, \\ M. Gibb, K. Ball, J. M. McDiarmid and D. C. Thurley \\ Wallaceville Animal Research Centre, Research Division, Ministry of Agriculture and Fisheries, \\ Private Bag, Upper Hutt, New Zealand
}

\begin{abstract}
Summary. Overall, significantly more antral follicles $\geqslant 1 \mathrm{~mm}$ diameter were present in Romney ewes during anoestrus than in the breeding season (anoestrus, $35 \pm 3$ (mean \pm s.e.m.) follicles per ewe, 23 sheep; Day 9-10 of oestrous cycle, $24 \pm 1$ follicles per ewe, 22 sheep; $P<0.01$ ), although the mean numbers of preovulatory-sized follicles ( $\geqslant 5 \mathrm{~mm}$ diam.) were similar (anoestrus, $1.3 \pm 0.2$ per ewe; oestrous cycle, $1.0 \pm 0.1$ per ewe). The ability of ovarian follicles to synthesize oestradiol did not differ between anoestrus and the breeding season as assessed from the levels of extant aromatase enzyme activity in granulosa cells and steroid concentrations in follicular fluid. Although the mean plasma concentration of LH did not differ between anoestrus and the luteal phase of the breeding season, the pattern of LH secretion differed markedly; on Day 9-10 of the oestrous cycle there were significantly more $(P<0.001)$ highamplitude LH peaks (i.e. $\geqslant 1 \mathrm{ng} / \mathrm{ml})$ in plasma and significantly fewer $(P<0.001)$ low amplitude peaks $(<1 \mathrm{ng} / \mathrm{ml})$ than in anoestrous ewes. Moreover, the mean concentrations of FSH and prolactin were significantly lower during the luteal phase of the cycle than during anoestrus (FSH, $P<0.05$, prolactin, $P<0.001$ ).

It is concluded that, in Romney ewes, the levels of antral follicular activity change throughout the year in synchrony with the circannual patterns of prolactin and daylength. Also, these data support the notion that anovulation during seasonal anoestrus is due to a reduced frequency of high-amplitude LH discharges from the pituitary gland.
\end{abstract}

\section{Introduction}

In temperate-zone latitudes, most breeds of sheep are anovulatory and anoestrous during the spring and summer. Although limited, the data suggest that the ovaries of anoestrous ewes are relatively active with respect to follicular development and steroidogenesis. For example, the antral follicle population is reported to be similar to or lower than that found during the breeding season (Cole \& Miller, 1935; Kammlade, Welch, Nalbandov \& Norton, 1952; Cahill, 1979), and the ovaries of anoestrous ewes secrete androstenedione and oestradiol when stimulated with luteinizing hormone (LH) (Martensz, Baird, Scaramuzzi \& Van Look, 1976; Scaramuzzi \& Baird, 1977). It is possible that a reduced level of LH secretion may be the major cause of anovulation during anoestrus (Legan, Karsch \& Foster, 1977; McNatty, Gibb, Dobson \& Thurley, 1981b). The long-term administration of regular intravenous (i.v.) pulses of LH or gonadotrophin-releasing hormone 
( $\mathrm{GnRH})(10 \mu \mathrm{g}$ ovine $\mathrm{LH}$ or $500 \mathrm{ng}$ GnRH every $2 \mathrm{~h})$ stimulated cyclic luteal activity comparable to that seen during the breeding season (McNatty, Ball, Gibb, Hudson \& Thurley, 1982a; McNatty et $a l ., 1983 \mathrm{~b}$ ); in these studies the resulting LH pulse frequencies in plasma were similar to those observed during the luteal phase of the oestrous cycle (McNatty et al., 1981b). Presumably, ovulation does not occur during the luteal phase, when there is an LH pulse frequency of 1 per $2 \mathrm{~h}$, because of the combined negative feedback effects of oestradiol from the developing follicle and progesterone from the corpus luteum (Baird, Baker, McNatty \& Neal, 1975). Although some data are available on seasonal changes in LH, follicle-stimulating hormone (FSH) and prolactin in sheep (Walton, McNeilly, McNeilly \& Cunningham, 1977; Jackson \& Davis, 1979; Munro, McNatty \& Renshaw, 1980), little or no attempt has been made to examine how these changes in gonadotrophin secretory activity relate to seasonal changes in ovarian follicular and steroidogenic activity.

The objectives of this study of Romney ewes were (1) to determine the degree of antral follicle development throughout the year, and (2) to ascertain the circannual patterns of LH, FSH and prolactin secretion and to relate these changes to the degree of follicular activity within the ovary.

\section{Materials and Methods}

Animals and experimental design

Parous Romney ewes (40-64 kg) aged between $2 \cdot 2$ and $3 \cdot 2$ years were used. Throughout the year, the animals were grazed on pasture and were run with sexually active vasectomized rams fitted with marking harnesses. Oestrous behaviour was not observed in any ewe from September to February (inclusive). During the breeding season (March-August), ovarian dissections were performed on Day 9 or 10 of the oestrous cycle (on 3-7 animals per month), or on Day 9-10 but 10$48 \mathrm{~h}$ after ewes were treated with cloprostenol (125 $\mu \mathrm{g}$ s.c.), a synthetic prostaglandin F- $2 \alpha$ derivative (ICI Tasman Ltd, Upper Hutt, NZ). In the ewes treated with cloprostenol, ovariectomy was performed at 10,24, 36 and $48 \mathrm{~h}$ after cloprostenol injection ( 3 ewes at each time). Some animals (4-18 each month) that were not treated with cloprostenol were blood sampled every 10 $\min$ for $9 \mathrm{~h}$ (for $\mathrm{LH}$ and FSH determinations) on Day 9 or 10 of the oestrous cycle. On the day before intensive blood sampling, the animals were penned indoors and each was fitted with an intrajugular cannula. While indoors, the animals were fed meadow hay, lucerne pellets and water $a d$ libitum. Animals were selected at random from a flock of 350 ewes; individual animals were not sampled in successive months. One group of 8 ewes was blood sampled every 3 rd day throughout the year for prolactin determinations; these ewes were grazed in a separate paddock from the main flock. Before this study began, the animals in the prolactin study were blood sampled 3 times weekly for 6 weeks to accustom them to handling and blood sampling procedures. The 8 ewes were anoestrous from September to February and showed oestrus at regular intervals from March until August.

\section{Blood sampling}

From the sheep in the prolactin study, $10 \mathrm{ml}$ blood were collected on each occasion. From the other sheep 2-4 ml blood were taken at each occasion into a heparinized tube. All blood samples were centrifuged $\left(4000 \mathrm{~g}\right.$ at $18-20^{\circ} \mathrm{C}$ for $20 \mathrm{~min}$ ) within $15 \mathrm{~min}$ of collection, the plasma samples were then frozen to $-20^{\circ} \mathrm{C}$ until assayed.

\section{Ovarian studies}

Excised ovaries were weighed and their gross morphology recorded. All individual antral follicles ( $\geqslant 1 \mathrm{~mm}$ diameter) were dissected free of extraneous tissue under a stereomicroscope and 
their diameters recorded. A small slit was made in the follicle wall to allow the antral fluid to escape into a Petri dish whence it was aspirated through a finely drawn-out Pasteur pipette, taking care not to remove clumps or sheets of granulosa cells. The fluid was frozen for subsequent hormone assay. The granulosa cells were recovered and their number quantitated as previously described (McNatty, Moore-Smith, Makris, Osathanondh \& Ryan, 1979). During recovery of follicular fluid or granulosa cells the oocyte was also isolated and its status assessed subjectively as healthy or degenerate as previously described (McNatty et al., 1983a). To help classify the follicles as healthy or atretic, the presence or absence of thecal blood capillaries (at $\times 10$ magnification) and debris in follicular fluid was noted. In addition, after removal of the granulosa cells, the colour of the theca interna (i.e. red, pink or white) was noted. For the purpose of this study a healthy follicle was defined as one with: (a) thecal blood capillaries visible at $\times 10$ magnification, (b) follicular fluid devoid of debris, (c) an apparently healthy oocyte, (d) a pink-to-red coloured theca interna, and (e) $\geqslant 50 \%$ of the maximum number of granulosa cells for a given follicle size (McNatty et al., 1982b). Conversely, an atretic follicle was one for which any of these criteria did not apply.

\section{The granulosa cell aromatase assay}

From some of the follicles recovered during the cloprostenol-induced follicular phase, Day 9-10 of the cycle or anoestrus, the granulosa cells were collected into Medium 199 containing sodium bicarbonate $(0.85 \mathrm{~g} / \mathrm{l})$, Earle's salts, L-glutamine $(0.10 \mathrm{~g} / \mathrm{l})$, Hepes buffer $(20 \mathrm{MM})$ and $1 \%$ BSA $(\mathrm{w} / \mathrm{v})$, Medium A. These were washed and resuspended in Medium A so that the final cell concentration was $60-600 \times 10^{3}$ granulosa cells per $\mathrm{ml} ; 0.5 \mathrm{ml}$ aliquants of these cell suspensions were placed in $10 \times 75 \mathrm{~mm}$ plastic tubes containing $0.5 \mathrm{ml}$ of a solution of $2000 \mathrm{ng}$ testosterone/ml Medium A, gassed with $5 \% \mathrm{CO}_{2}$ in air, stoppered and then incubated for $3 \mathrm{~h}$ in a shaking water bath at $37^{\circ} \mathrm{C}$. At the end of the incubation, the tubes, containing medium plus cells, were frozen at $-20^{\circ} \mathrm{C}$. Subsequently the tubes were thawed, centrifuged and the supernatant assayed for oestradiol. Preliminary studies revealed that the rate of oestradiol formation was linear for the first $3 \mathrm{~h}$ for granulosa cells from all atretic follicles and from most healthy follicles. In some of the healthy follicles, however, the rate of metabolism was not linear after $2 \mathrm{~h}$ so that the results in some instances underestimated extant oestrogen synthetase (aromatase) activity by up to $20 \%$.

\section{Hormone assays}

$L H$. The radioimmunoassay for $\mathrm{LH}$ was identical to that reported by McNatty, Gibb, Dobson, Thurley \& Findlay (1981 a). The LH antibody raised in a rabbit against NIH-LH-S11 was used at an initial dilution of $1: 40000$. The antiserum exhibited low cross-reactions with other ovine pituitary hormones: prolactin (NIH-P-S12), 0.09\%; TSH (NIH-TSH-S 8 ), 2.4\%; GH (NIH-GH-S11), 0.4\%; and FSH (NIH-FSH-S10), $0.4 \%$. The within- and between-assay coefficients of variation were 6.8 and $10.3 \%$ respectively. The limit of detection was $0.2 \mathrm{ng} \mathrm{LH} / \mathrm{ml}$ plasma.

$F S H$. The radioimmunoassay for FSH was based on that described by Salamonsen et al. (1973). The standard preparation was NIH-FSH-10 and a Papkoff preparation, G4-150C, was used as the iodinated tracer. Rabbit anti-human FSH (M94) was supplied by Dr W. Butt, and was used at an initial dilution of $1: 8000$. Cross-reactions with other ovine pituitary hormones were: LH (NIHLH-S21), $<0.5 \%$; prolactin (NIH-P-S18), <0.5\%; GH (NIH-GH-S11), $<0.5 \%$; and TSH (NIHTSH-S 8$)<0.5 \%$. The within- and between-assay coefficients of variation were 8.5 and $15.0 \%$ respectively. The limit of detection was $20 \mathrm{ng}$ FSH/ml plasma.

Only a limited amount of FSH antiserum was available for this study. Therefore, of the 85 sheep blood sampled for seasonal changes in LH secretion, 43 (2-6 each month) were selected for FSH analysis.

Prolactin. Prolactin in plasma was measured by the method of Munro et al. (1980). Ovine prolactin NIH-P-S11 was used as the reference standard and ovine prolactin LER-860-2 as the 
iodinated tracer. Rabbit antiserum to ovine prolactin (NIH-P-S6) was supplied by Dr J. R. McNeilly. Details of cross-reactions and characterization of the antiserum have been described by Lamming, Moseley \& McNeilly (1974). The within- and between-assay coefficients of variation were 6.5 and $15.0 \%$ respectively. The minimal detectable concentration of prolactin was $2.0 \mathrm{ng} / \mathrm{ml}$ plasma.

Steroids. All steroids were measured using previously published radioimmunoassay procedures (McNatty et al., 1981a, 1982b). Progesterone, androstenedione and oestradiol were measured directly in diluted (10-100-fold with 0.1 M-phosphate-buffered saline (PBS), pH 7.2) aliquants of follicular fluid. Testosterone was measured in follicular fluid after it had been diluted (10-100-fold) with PBS and extracted twice with 5 volumes of freshly redistilled diethyl ether.

Oestradiol was measured directly in Medium A (the aromatase assay solution) without extraction.

For the progesterone antiserum (WA-26), the major cross-reacting steroids were $11 \alpha$ -

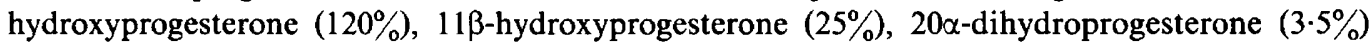
and androstenedione $(0 \cdot 4 \%)$. The minimal detectable quantity of progesterone was $1 \mathrm{ng} / \mathrm{ml}$ antral fluid.

The androstenedione antiserum (WA-965) was used at an initial dilution of 1:3000. Major cross-reacting steroids were 4 -androsten-3,11,17-trione $(40 \%), 11 \beta$-hydroxyandrostenedione $(31 \%)$ and testosterone $(0.4 \%)$. The detection limit of this assay was $2 \mathrm{ng} / \mathrm{ml}$ antral fluid.

The testosterone antiserum (WA-36) was used at an initial dilution of 1:800. Major crossreacting steroids were $5 \alpha$-dihydrotestosterone $(75 \%), 5 \beta$-dihydrotestosterone $(75 \%), 5 \alpha$-androstan$3 \alpha, 17 \beta$-diol $(37.5 \%)$, $5 \beta$-androstan- $3 \alpha, 17 \beta$-diol $(16.5 \%)$ and androstenedione $(0.1 \%)$. The detection limit of the assay was $1 \mathrm{ng} / \mathrm{ml}$ antral fluid. Since the first mentioned $5 \alpha$ - or $5 \beta$-reduced androgens cross-reacted in significant amounts, the testosterone concentrations may have been overestimated in samples containing appreciable quantities of $5 \alpha$ - or $5 \beta$-dihydrotestosterone (DHT). Forty-two individual samples of follicular fluid were fractionated by celite chromatography to separate DHT from testosterone (McNatty et al., 1982b) and to determine the extent of DHT interference in the testosterone assay. The fluid samples were from large ( $\geqslant 5 \mathrm{~mm} \mathrm{diam}$.), intermediate (3-4 mm diam.) and small ( $\leqslant 2 \mathrm{~mm}$ diam.) healthy and atretic follicles. The mean testosterone concentration was $39 \pm 6$ (s.e.m.) $\mathrm{ng} / \mathrm{ml}$ and the mean DHT concentration $4 \pm 1$ (s.e.m.) $\mathrm{ng} / \mathrm{ml}$. Overall the fraction of DHT as a percentage of the total amount of testosterone plus DHT was $12 \cdot 2 \pm 2.5$ (s.e.m.) $\%$. In 3 samples the DHT concentrations were high $(>20 \mathrm{ng} / \mathrm{ml}$ ) and exceeded those of testosterone; these fluids were from small atretic follicles.

The oestradiol antiserum (WA-27) was used at an initial dilution of 1:16000 and major crossreacting steroids with this antiserum were oestrone $(7.3 \%)$, oestriol $(1.4 \%)$ and oestradiol- $17 \alpha$ $(1.4 \%)$. The detection limit for antral fluid was $1 \mathrm{ng} / \mathrm{ml}$ and for the aromatase assay $50 \mathrm{pg} / \mathrm{ml}$.

The intra- and inter-assay coefficients of variation for all the above steroid assays were $<12 \%$.

\section{Seasonal daylength changes at Wallaceville}

The Wallaceville Animal Research Centre is situated at $41^{\circ} 08^{\prime} \mathrm{S}$ and $173^{\circ} 03^{\prime} \mathrm{E}$. The mean monthly daylength changes for 1980 were calculated from sunrise and sunset tables supplied by the New Zealand Meteorological Service (Government Printing Office, Wellington, New Zealand). The mean numbers of daylight hours for each month from January to December were 14.5, 13.6, $12 \cdot 2,10 \cdot 9,9 \cdot 9,9 \cdot 1,9 \cdot 3,10 \cdot 4,12 \cdot 0,13 \cdot 1,14 \cdot 5$ and $15 \cdot 1 \mathrm{~h}$. These data were used when correlating possible seasonal changes in basal gonadotrophin concentrations or follicle number with daylength.

\section{Definitions}

LH peak. The criteria used to define an LH peak were modifications of those described by Van Look (1976) and an LH peak was identified if (a) the concentrations of LH in at least 2 consecutive 
samples ('the peak samples') were higher than the mean of the previous 2 samples ('baseline' samples), and if (b) the increase above baseline in at least one of the 'peak samples' was greater than 4 times the within-assay variation.

LH amplitude. The amplitude of the LH peak was defined as the difference between the highest $\mathrm{LH}$ value of the peak and the mean of the two baseline samples. A high-amplitude peak was defined as one with an $\mathrm{LH}$ value of $\geqslant 1 \mathrm{ng} / \mathrm{ml}$, whereas a low-amplitude peak was one with an LH value of $<1 \mathrm{ng} / \mathrm{ml}$ (McNatty et al., 1981b).

\section{Statistics}

When appropriate the normalized data were subjected to analysis of variance followed by Student's $t$ test.

\section{Results}

Changes in ovarian weight, follicle size, distribution and incidence of healthy follicles throughout the year

These data are summarized in Text-fig. 1. The mean ( \pm s.e.m.) weight of ovaries during anoestrus was $0.95 \pm 0.03 \mathrm{~g}(n=46)$ and, during Day 9-10 of the breeding season, the mean $( \pm$ s.e.m.) weights of ovaries with and without $\mathrm{CL}$, were, respectively, $1.63 \pm 0.04 \mathrm{~g}(n=22)$ and 0.93 $\pm 0.04 \mathrm{~g}(n=22)$. During the transitional period of oestrus-anoestrus (August-September), the mean weight of an ovary not containing a $C L$ was uniformly low, i.e. $0.77 \pm 0.04 \mathrm{~g}(n=14)$.

Throughout the year, most follicles $\geqslant 1 \mathrm{~mm}$ diameter (i.e. $60-80 \%$ ) were $1-2 \mathrm{~mm}$ in diameter. Proportionately, preovulatory-sized follicles represented the smallest population (i.e. $2-10 \%$ ) but they were present every month of the year.

The mean number of healthy follicles of each size range (i.e. 1-2, 3-4 or $\geqslant 5 \mathrm{~mm}$ diam.) varied throughout the year with the proportions of each size range changing in a similar pattern (Text-fig. 1c). The majority of $1-2 \mathrm{~mm}$ diameter follicles $(\geqslant 70 \%$ were atretic. For the $1-2 \mathrm{~mm}$ and $3-4 \mathrm{~mm}$ diameter follicles the lowest mean proportions of healthy follicles were recorded during August, September and October. For most of anoestrus (i.e. November, December, January and February) the mean proportions of healthy follicles for all diameters were high compared to the rest of the year (Text-fig. 1c).

\section{Changes in the number of antral follicles ( $\geqslant 1 \mathrm{~mm}$ diameter) throughout the year}

These data are summarized in Text-fig. 2. Overall, there were significantly more antral follicles ( $\geqslant 1 \mathrm{~mm}$ diam.) during anoestrus compared to the breeding season (anoestrus, $35 \pm 3$ (s.e.m.), 23 sheep; Day 9-10 of the oestrous cycle, $24 \pm 1$ (s.e.m.), 22 sheep; $P<0.01$ ). The mean number of preovulatory-sized follicles ( $\geqslant 5 \mathrm{~mm}$ diam.) per ewe did not differ significantly between anoestrus and the breeding season (anoestrus $1 \cdot 3 \pm 0 \cdot 2$ (s.e.m.), 23 sheep; Day 9-10 of the oestrous cycle, 1.0 $\pm 0 \cdot 1$ (s.e.m.), 22 sheep). Linear regression analysis of the mean monthly follicle number (Text-fig. 2) with the mean monthly hours of daylength (see 'Materials and Methods') showed that there was an association between the two parameters with a correlation coefficient of $0.82(P<0.001)$.

\section{Steroid concentrations in follicular fluid of healthy and atretic follicles}

These data are summarized in Table 1. The pattern of steroidogenesis during anoestrus (as represented by steroid concentrations in follicular fluid) was similar to that during the luteal phase of the oestrous cycle. Of the steroids measured, the major ones in healthy follicles $\geqslant 3 \mathrm{~mm}$ diameter throughout the year were consistently oestradiol and testosterone. Regardless of the time of the 


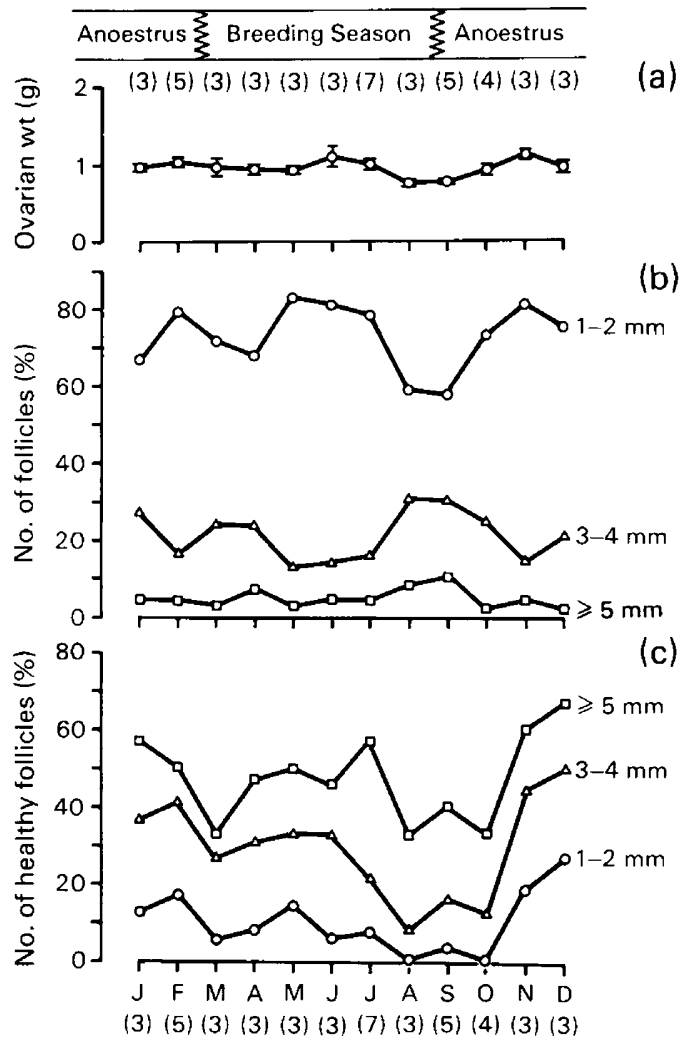

Text-fig. 1. Mean monthly changes in: (a) ovarian weight; (b) number of follicles of different diameter per ewe expressed as percentage of the total population of follicles $\geqslant 1 \mathrm{~mm}$ in diameter; and (c) number of healthy follicles per ewe expressed as a percentage of follicles in each size range. During the breeding season the data refer to ovaries recovered on Day 9-10 of the oestrous cycle. In (a) the vertical bars $= \pm$ s.e.m., and the mean monthly weights refer to ovaries devoid of corpora lutea. In (b) and (c) the follicular data refer to all ovaries and do not discriminate between those with or without corpora lutea. The number of ewes examined in each month is indicated.

oestrous cycle or year, small (1-2 mm diam.) antral follicles were steroidogenically active and the healthy ones, at least, were capable of synthesizing some oestradiol.

Only large healthy follicles ( $\geqslant 5 \mathrm{~mm}$ diam.) during the follicular phase contained intrafollicular levels of oestradiol most frequently above $90 \mathrm{ng} / \mathrm{ml}$.

\section{Extant aromatase activity in granulosa cells}

These data with respect to follicle size and health are summarized in Table 2 . Since the mean level of aromatase activity in granulosa cells from large healthy follicles ( $\geqslant 5 \mathrm{~mm}$ diam.) on Day 9 10 of the oestrous cycle $\left(6.6 \pm 1 \cdot 0 \mathrm{ng} / 10^{6}\right.$ cells $\left./ 3 \mathrm{~h}, n=5\right)$ was not different from that in cells from healthy follicles of similar size during the follicular phase $(5 \cdot 7 \pm 0 \cdot 9, n=9)$, all the data from the breeding season were pooled as indicated above.

There was no effect of season on the level of extant aromatase activity in cells from small (1-2 $\mathrm{mm}$ diam.), medium (3-4 mm diam.) or large follicles ( $\geqslant 5 \mathrm{~mm}$ diam.). In the healthy follicles, extant aromatase activity increased with increasing follicular size. In general, aromatase activity, 


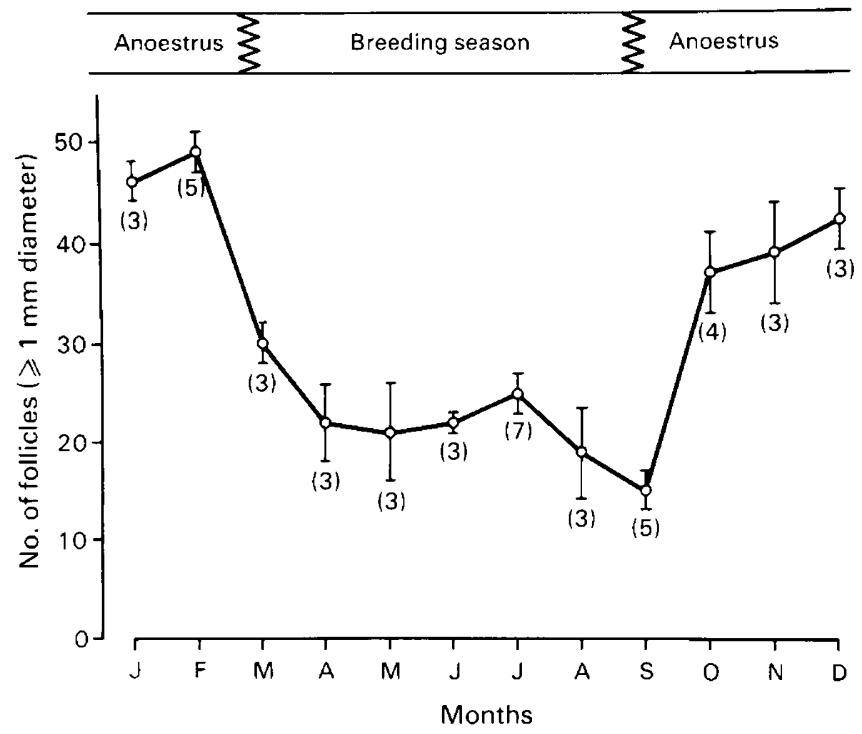

Text-fig. 2. Mean \pm s.e.m. monthly changes in the antral follicle population ( $\geqslant 1 \mathrm{~mm}$ diam.) per ewe (number in parentheses). During the breeding season the follicle numbers refer only to ovaries recovered on Day 9-10 of the oestrous cycle.

when assessed using $1000 \mathrm{ng}$ testosterone substrate, was higher in healthy than atretic follicles; this difference was most obvious in the preovulatory-sized follicles.

\section{LH concentration}

The data summarizing the concentration of $\mathrm{LH}, \mathrm{LH}$ peak frequency and $\mathrm{LH}$ peak amplitude in Romney ewes on Day 9-10 of the oestrous cycle and during anoestrus are shown in Table 3 . There was no significant difference in the mean $\mathrm{LH}$ concentration between the two intervals although differences in the pattern of LH secretion were noted. On Day 9-10 there were significantly more $(P<0.001)$ high-amplitude peaks and significantly fewer $(P<0.001)$ low-amplitude peaks compared to those in anoestrous ewes. The respective mean amplitudes of the high- and lowamplitude peaks during each season were similar.

When the data for LH concentrations (Text-fig. 3; Table 3), the overall LH peak frequency and the low amplitude peak frequency (Table 3 ) were analysed month by month no obvious seasonallyrelated trends or differences were noted. However, the monthly data for the high-amplitude peak frequency showed consistently high peak frequencies from March until July; the respective means \pm s.e.m. of the high-amplitude peak frequency per $9 \mathrm{~h}$ for these months were $6.2 \pm 0.6$ ( 9 ewes), 4.7 $\pm 1 \cdot 0(6), 5 \cdot 0 \pm 0 \cdot 5(5), 5 \cdot 6 \pm 1 \cdot 6(4), 6 \cdot 4 \pm 0 \cdot 8(4)$. Thereafter from August, the high-amplitude LH peak frequency declined steadily until November; the respective means \pm s.e.m. per $9 \mathrm{~h}$ for each of these months were: $4.0 \pm 0.4$ (4 ewes), $3.4 \pm 0.5$ (4), $2.5 \pm 0.2$ (18) and $1.8 \pm 0.4$ (12). During December, January and February, the high-amplitude LH peak frequencies remained $<3$ peaks $/ 9$ h (i.e. $2 \cdot 4 \pm 0.4,2.3 \pm 0.4$ and $2.5 \pm 0.5$ peaks $/ 9 \mathrm{~h}$ respectively) until the onset of the breeding season.

\section{FSH concentrations}

The mean plasma concentrations of FSH each month of the year are shown in Text-fig. 3 . Overall, the mean ( \pm s.e.m.) concentration during the breeding season $(117 \pm 8 \mathrm{ng} / \mathrm{ml}, 20 \mathrm{sheep})$ 
Table 1. Steroids in ovine follicular fluid (values are geometric means and $95 \%$ confidence limits)

\begin{tabular}{|c|c|c|c|c|c|c|c|}
\hline \multirow{2}{*}{$\begin{array}{l}\text { Reproductive } \\
\text { status }\end{array}$} & \multirow{2}{*}{$\begin{array}{l}\text { Follicle } \\
\text { status }\end{array}$} & \multirow{2}{*}{$\begin{array}{l}\text { Follicle } \\
\text { diameter } \\
(\mathrm{mm})\end{array}$} & \multirow[b]{2}{*}{$n$} & \multicolumn{4}{|c|}{ Steroid concentration $(\mathrm{ng} / \mathrm{ml})$} \\
\hline & & & & $P$ & $\Delta_{4}$ & $\mathbf{T}$ & $\mathrm{E}_{2}$ \\
\hline \multirow[t]{2}{*}{ Luteal* } & Healthy & $\geqslant 5$ & 10 & $\begin{array}{c}8 \\
(5,14)\end{array}$ & $\begin{array}{c}7 \\
(4,12)\end{array}$ & $\begin{array}{c}35 \\
(16,76)\end{array}$ & $\begin{array}{c}44 \\
(14,137)\end{array}$ \\
\hline & Atretic & & 5 & $\begin{array}{c}15 \\
(5,47)\end{array}$ & $\begin{array}{c}8 \\
(2,37)\end{array}$ & $\begin{array}{c}32 \\
(15,65)\end{array}$ & $\begin{array}{c}9 \\
(6,14)\end{array}$ \\
\hline \multirow[t]{2}{*}{ Folliculart } & Healthy & & 12 & $\begin{array}{c}15 \\
(11,22)\end{array}$ & $\begin{array}{c}16 \\
(10,27)\end{array}$ & $\begin{array}{c}37 \\
(21,66)\end{array}$ & $\begin{array}{c}184 \\
(90,378)\end{array}$ \\
\hline & Atretic & & 15 & $\begin{array}{c}20 \\
(10,38)\end{array}$ & $\begin{array}{c}10 \\
(5,19)\end{array}$ & $\begin{array}{c}9 \\
(5,15)\end{array}$ & $\begin{array}{c}10 \\
(6,17)\end{array}$ \\
\hline \multirow[t]{2}{*}{ Anoestrous: } & Healthy & & 21 & $\begin{array}{c}8 \\
(6,12)\end{array}$ & $\begin{array}{c}9 \\
(6,12)\end{array}$ & $\begin{array}{c}16 \\
(10,26)\end{array}$ & $\begin{array}{c}31 \\
(21,47)\end{array}$ \\
\hline & Atretic & & 22 & $\begin{array}{c}9 \\
(7,11)\end{array}$ & $\begin{array}{c}11 \\
(8,16)\end{array}$ & $\begin{array}{c}25 \\
(16,37)\end{array}$ & $\begin{array}{c}8 \\
(3,18) \\
\end{array}$ \\
\hline \multirow[t]{2}{*}{ Luteal* $^{*}$} & Healthy & $3-4$ & 15 & $\begin{array}{c}13 \\
(8,13)\end{array}$ & $\begin{array}{c}11 \\
(7,16)\end{array}$ & $\begin{array}{c}37 \\
(22,64)\end{array}$ & $\begin{array}{c}37 \\
(20,67)\end{array}$ \\
\hline & Atretic & & 13 & $\begin{array}{c}13 \\
(8,21)\end{array}$ & $\begin{array}{c}10 \\
(7,16)\end{array}$ & $\begin{array}{c}17 \\
(11,25)\end{array}$ & $\begin{array}{c}9 \\
(6,14)\end{array}$ \\
\hline \multirow[t]{2}{*}{ Follicular $\dagger$} & Healthy & & 16 & $\begin{array}{c}9 \\
(5,16)\end{array}$ & $\begin{array}{c}14 \\
(7,27)\end{array}$ & $\begin{array}{c}25 \\
(15,40)\end{array}$ & $\begin{array}{c}29 \\
(22,51)\end{array}$ \\
\hline & Atretic & & 19 & $\begin{array}{c}22 \\
(14,33)\end{array}$ & $\begin{array}{c}28 \\
(18,44)\end{array}$ & $\begin{array}{c}33 \\
(21,53)\end{array}$ & $\begin{array}{c}20 \\
(14,29)\end{array}$ \\
\hline \multirow[t]{2}{*}{ Anoestrous $\ddagger$} & Healthy & & 18 & $\begin{array}{c}12 \\
(8,16)\end{array}$ & $\begin{array}{c}7 \\
(5,10)\end{array}$ & $\begin{array}{c}30 \\
(21,44)\end{array}$ & $\begin{array}{c}25 \\
(16,39)\end{array}$ \\
\hline & Atretic & & 45 & $\begin{array}{c}12 \\
(10,15)\end{array}$ & $\begin{array}{c}12 \\
(10,14)\end{array}$ & $\begin{array}{c}37 \\
(25,40)\end{array}$ & $\begin{array}{c}7 \\
(2,9)\end{array}$ \\
\hline \multirow[t]{2}{*}{ Luteal* } & Healthy & $1-2$ & 15 & $\begin{array}{c}13 \\
(7,20)\end{array}$ & $\begin{array}{c}10 \\
(6,19)\end{array}$ & $\begin{array}{c}43 \\
(29,64)\end{array}$ & $\begin{array}{c}28 \\
(9,28)\end{array}$ \\
\hline & Atretic & & 6 & $\begin{array}{c}20 \\
(15,29)\end{array}$ & $\begin{array}{c}10 \\
(8,12)\end{array}$ & $\begin{array}{c}33 \\
(22,49)\end{array}$ & $\begin{array}{c}12 \\
(7,22)\end{array}$ \\
\hline \multirow[t]{2}{*}{ Follicular† } & Healthy & & 19 & $\begin{array}{c}9 \\
(6,12)\end{array}$ & $\begin{array}{c}19 \\
(11,31)\end{array}$ & $\begin{array}{c}50 \\
(37,67)\end{array}$ & $\begin{array}{c}32 \\
(22,49)\end{array}$ \\
\hline & Atretic & & 3 & $\begin{array}{c}15 \\
(8,28)\end{array}$ & $\begin{array}{c}64 \\
(28,148)\end{array}$ & $\begin{array}{c}37 \\
(18,77)\end{array}$ & $\begin{array}{c}8 \\
(2,32)\end{array}$ \\
\hline \multirow[t]{2}{*}{ Anoestrous $\ddagger$} & Healthy & & 12 & $\begin{array}{c}11 \\
(7,17)\end{array}$ & $\begin{array}{c}15 \\
(11,22)\end{array}$ & $\begin{array}{c}54 \\
(37,81)\end{array}$ & $\begin{array}{c}12 \\
(7,20)\end{array}$ \\
\hline & Atretic & & 74 & $\begin{array}{c}12 \\
(10,16)\end{array}$ & $\begin{array}{c}14 \\
(12,17)\end{array}$ & $\begin{array}{c}54 \\
(22,135)\end{array}$ & $\begin{array}{c}6 \\
(5,7)\end{array}$ \\
\hline
\end{tabular}

* Ovaries recovered on Days 9 and 10 of the oestrous cycle (Day $0=$ day of oestrus).

† Ovaries recovered between 10 and $48 \mathrm{~h}$ after induction of luteolysis with cloprostenol (125 $\mu \mathrm{g} \mathrm{s.c.}$ ) (see $\mathrm{McNatty}$ et al., 1982b).

$\ddagger$ Ovaries recovered from anovulatory ewes between September and February.

$n=$ number of follicles tested $\mathrm{P}=$ progesterone $; \Delta_{4}=$ androstenedione $; \mathrm{T}=$ testosterone; $\mathrm{E}_{2}=$ oestradiol-17 $\beta$.

was significantly lower $(P<0.05)$ than that during the non-breeding season $(158 \pm 16 \mathrm{ng} / \mathrm{ml}, n=$ 23). In general the range of values for each animal over a $9 \mathrm{~h}$ interval varied by $<20 \%$. But although the within-animal variation was small, the monthly variation between animals was at times as much as $300 \%$ (Text-fig. 3). Despite this between-animal variation, the mean concentrations of FSH were persistently elevated, 170-220 ng/ml, during October, November and December. These high mean values were the result of $8 / 12(66.7 \%)$ sheep ( $3 / 4$ during both October and November and $2 / 4$ during December) having FSH values in excess of $170 \mathrm{ng} / \mathrm{ml}$. In contrast, mean FSH values $>170 \mathrm{ng} / \mathrm{ml}$ were recorded on only $3 / 31(9.7 \%)$ other occasions throughout the year. 
Table 2. Extant aromatase activity (ng oestradiol $/ 10^{6}$ granulosa cells $/ 3 \mathrm{~h}$ ) in follicles of sheep in the breeding season and during anoestrus

\begin{tabular}{|c|c|c|c|c|}
\hline \multirow{2}{*}{$\begin{array}{c}\text { Follicle } \\
\text { diameter } \\
(\mathrm{mm})\end{array}$} & \multicolumn{2}{|c|}{ Healthy follicles } & \multicolumn{2}{|c|}{ Atretic follicles } \\
\hline & Breeding season & Anoestrus & Breeding season & Anoestrus \\
\hline$\geqslant 5$ & $6 \cdot 00 \pm \frac{ \pm}{(14)}$ & $6.59 \pm 0.71^{\mathrm{a}, \mathrm{e}}$ & $0 \cdot 30 \pm \underbrace{0 \cdot 11^{b, c}}_{(6)}$ & $0.26 \underset{(12)}{ \pm} 0.08^{\mathrm{b}, \mathrm{c}}$ \\
\hline $3-4$ & $3.77 \pm 0.55^{\mathrm{a}, \mathrm{c}}$ & $3.59 \pm 0.56^{\mathbf{a}, \mathrm{d}}$ & $0.21 \underset{(35)}{ \pm 0.06^{\mathbf{b}, \mathbf{c}}}$ & $0.29 \pm \frac{ \pm 0.06^{b, c}}{(34)}$ \\
\hline$\leq 2.5$ & $0.34 \pm 0.09^{\mathrm{a}, \mathrm{d}}$ & $0 \cdot 39 \pm 0 \cdot 10^{\mathrm{a}, \mathrm{f}}$ & $0 \cdot 16 \pm \frac{ \pm 02^{\mathrm{a}, \mathrm{c}}}{(42)}$ & $0.18 \pm \frac{ \pm 0.03^{\mathrm{a}, c}}{(46)}$ \\
\hline
\end{tabular}

Values are mean \pm s.e.m. with the no. of follicles tested in parentheses.

Mean values with different supercripts (a \& b) in the same row are different, superscripts (c, d, e \& f) in the same column are significantly different (a $v s \mathrm{~b}, \mathrm{c} v s \mathrm{~d}$, e $v s \mathrm{f}, \mathrm{d} v s \mathrm{f}, P<0.01$; e $v s \mathrm{~d}, P<0.05$ ) (analysis of variance (ANOVA) followed by Student's $t$ test between pairs using the variance from the ANOVA).

Table 3. The concentration of LH, LH peak frequency and $\mathrm{LH}$ peak amplitude (high $=\geqslant 1 \mathrm{ng} / \mathrm{ml}$; low $=<1 \mathrm{ng} / \mathrm{ml}$ ) in Romney ewes on Day 9-10 of the oestrous cycle and during anoestrus (results are means \pm s.e.m.)

\begin{tabular}{|c|c|c|c|c|c|c|c|c|}
\hline \multirow[b]{2}{*}{$\begin{array}{l}\text { Repro- } \\
\text { ductive } \\
\text { status }\end{array}$} & \multirow[b]{2}{*}{$\begin{array}{l}\text { No. of } \\
\text { sheep }\end{array}$} & \multirow[b]{2}{*}{$\begin{array}{c}\text { Overall LH } \\
\text { conc. } \\
\text { (ng/ml) }\end{array}$} & \multirow[b]{2}{*}{$\begin{array}{l}\text { Overall no. } \\
\text { of LH peaks } \\
\text { per } 9 \mathrm{~h}\end{array}$} & \multirow[b]{2}{*}{$\begin{array}{l}\text { Amplitude of } \\
\text { all recorded } \\
\text { peaks }(\mathrm{ng} / \mathrm{ml})\end{array}$} & \multicolumn{2}{|c|}{ High-amplitude peaks } & \multicolumn{2}{|c|}{ Low-amplitude peaks } \\
\hline & & & & & No. $/ 9 \mathrm{~h}$ & $\begin{array}{l}\text { Amplitude } \\
(\mathrm{ng} / \mathrm{ml})\left(n_{1}\right)\end{array}$ & No./9 h & $\begin{array}{l}\text { Amplitude } \\
(\mathrm{ng} / \mathrm{ml})\left(n_{2}\right)\end{array}$ \\
\hline Day 10 & 32 & $1 \cdot 8 \pm 0.1$ & $8.4 \pm 0.4$ & $2 \cdot 0 \pm 0.2$ & $5 \cdot 3 \pm 0 \cdot 4$ & $2 \cdot 8 \underset{(32)}{ \pm} 0.2$ & $3 \cdot 1 \pm 0.4$ & $0.5 \underset{(28)}{ \pm} 0.04$ \\
\hline Anoestrus & 53 & $1.7 \pm 0.1$ & $7 \cdot 4 \pm 0.3^{*}$ & $1.5 \pm 0.1 \dagger$ & $2.4 \pm 0.2 \ddagger$ & $3 \cdot 2 \underset{(49)}{ \pm} 0 \cdot 3$ & $5 \cdot 0 \pm 0 \cdot 3 \ddagger$ & $0.6 \underset{(51)}{ \pm} 0.02$ \\
\hline
\end{tabular}

Not all sheep gave records of low- or high-amplitude peaks; $n_{1}$ and $n_{2}$ indicate the number from which the respective mean amplitudes were calculated.

Significantly different from Day 9-10 value: ${ }^{*} P<0.05 ; \dagger P<0.005 ; \ddagger P<0.001$ (analysis of variance between each variable).

\section{Prolactin concentrations during the breeding season and anoestrus}

The mean plasma concentrations of prolactin each month for the year are shown in Text-fig. 3 . Overall, the mean \pm s.e.m. concentration during the breeding season $(15 \pm 1 \mathrm{ng} / \mathrm{ml}, n=48$ mean monthly values) was significantly lower $(P<0.001)$ than that during the non-breeding season (148 $\pm 16 \mathrm{ng} / \mathrm{ml}), n=48$ ). Linear regression analysis of the log-transformed mean monthly data for prolactin and the mean hours of daylight each month showed there was an association between the two parameters with a correlation coefficient of $0.64(P<0.01)$. Moreover, linear regression analysis of the mean monthly data for prolactin and follicle number gave a correlation coefficient of $0.84(P<0.01)$.

\section{Discussion}

These data demonstrate for the Romney ewe that antral follicular development is not constant throughout the year. During the breeding season and the first month of anoestrus, the number of antral follicles ( $\geqslant 1 \mathrm{~mm}$ diam.) per ewe was uniformly below 35 . In contrast, during most of anoestrus the antral follicle population was uniformly above 35 . The correlation between antral 


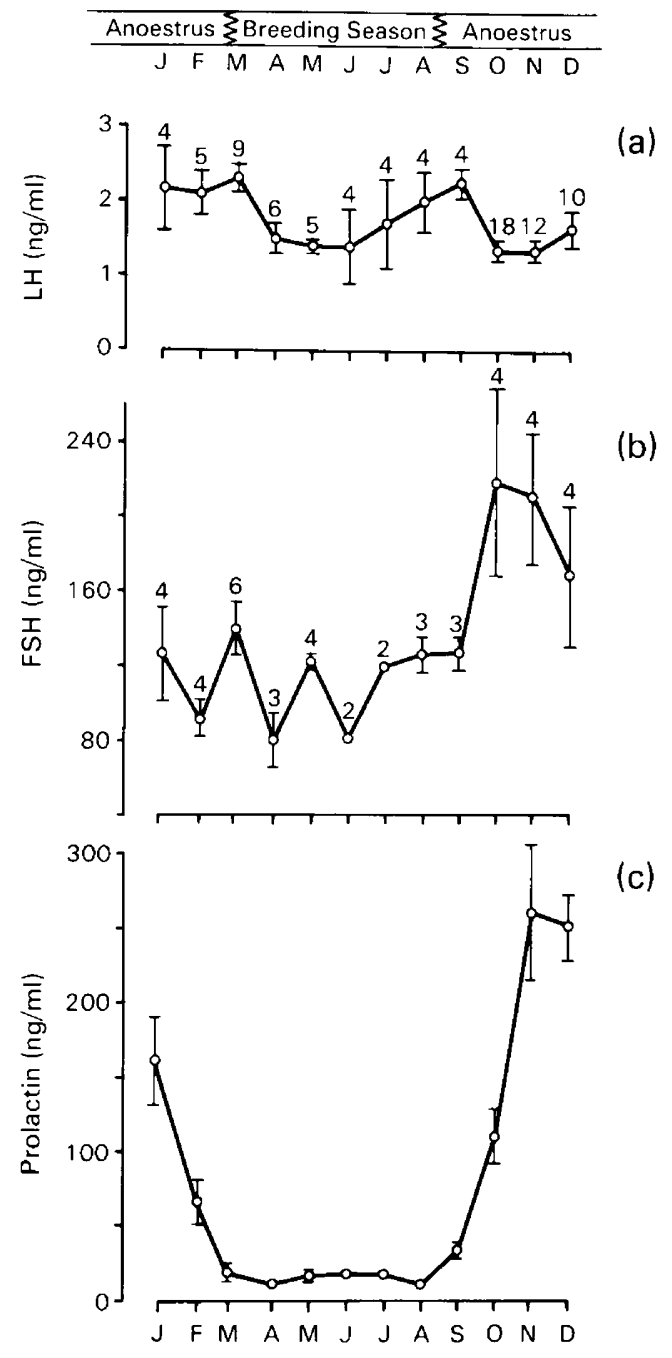

Text-fig. 3. Mean \pm s.e.m. monthly changes in plasma hormone concentrations of sheep (no. indicated). For LH and FSH, each ewe was sampled every $10 \mathrm{~min}$ for $9 \mathrm{~h}$ on Day 9 or 10 of the oestrous cycle or during anoestrus. Thus the mean value for each ewe was determined from 55 samples. For the monthly prolactin values, the same 8 ewes were bled by venepuncture every $3 r d$ day throughout the year so that the mean monthly value was determined from 9-10 samples. For further details see 'Materials and Methods'.

follicle number and hours of daylength suggest that perhaps the level of follicular activity is regulated by photoperiod. Although unexpected, the rapid decline in the follicle population after February coincided with the onset of the breeding season. However, at the end of the breeding season, the increase (or rebound) in the antral follicle number to that observed in January or February did not occur until October, i.e. not until 4-6 weeks after the last ovulation of the breeding season. The results of this study suggest that the end of the breeding season coincided with an overall reduction in ovarian activity. For example, the ovarian weights were uniformly lower in August and September than any other month of the year, the mean proportions of healthy, smalland medium-sized antral follicles were lowest in August, September and October, and, although some individual animal variation existed, the mean follicle population ( $\geqslant 1 \mathrm{~mm}$ diam.) was lowest 
in August and September. Whether these reductions in ovarian activity are associated with a lowered level of ovarian steroid secretion remains to be determined.

In a previous study, Cahill (1979) reported a significant correlation $(P<0.05)$ between the mean prolactin concentration during the luteal phase and the number of non-atretic preantral follicles. In the present study, the circannual pattern of antral follicular activity correlated significantly with the circannual patterns of prolactin secretion and daylength. Although these data could be used to reinforce the generally accepted theories that the environment, and primarily the photoperiodic component, influence hypothalamic-pituitary function and thereby gonadal activity (Lincoln \& Short, 1980; Arendt, Symons \& Laud, 1981; Karsch, Bittman \& Legan, 1981), the possibility exists that the high number of antral follicles during anoestrus are, in part, a consequence of a direct stimulatory effect of prolactin on the preantral follicle population.

The present studies confirm a previous report for Romney ewes that the mean plasma concentration of LH during the luteal phase is not significantly different from that during anoestrus (McNatty et al., 1981b). But, during the breeding season (on Day 9-10 of the oestrous cycle), the frequency of $\mathrm{LH}$ peaks (i.e. all peaks) per $9 \mathrm{~h}$ was 8.4 whereas during anoestrus the total peak frequency per $9 \mathrm{~h}$ was $7.4(P<0.05)$. By contrast, on Day $9-10$ of the cycle, the number of high and low amplitude $\mathrm{LH}$ peaks was $2 \cdot 2$ times and 0.6 times respectively of those values recorded during anoestrus. Any interpretation of the above $\mathrm{LH}$ data is critically dependent on the criteria used to define an LH peak (Van Look, 1976; see also Merriam \& Wachter, 1982) as well as the physiological significance of the LH peaks at the level of the ovary. In-vitro studies on the ovaries of cows and ewes have shown that the steroidogenic response of theca interna cells to $\mathrm{LH}$ is significantly enhanced by LH concentrations $\geqslant 1 \mathrm{ng} / \mathrm{ml}$ but not by those $<1 \mathrm{ng} / \mathrm{ml}$ (unpublished data). It is therefore possible that a low-amplitude $\mathrm{LH}$ peak reflects a low-amplitude secretion of pituitary LH and that some or all of these small pulses are without effect at the level of the ovary. If the low-amplitude peaks truly represent secretory episodes, then changes in LH secretory activity during the year could be due to changes in the amplitude as well as frequency of hypothalamic $\mathrm{GnRH}$ release. This line of reasoning suggests that seasonal changes in the frequency of GnRH release are small relative to the seasonal changes in amplitude, assuming that each pulse of GnRH releases a pulse of LH (McIntosh \& McIntosh, 1982). However, the possibility cannot be discounted that some of the so-called low-amplitude peaks represent interference ('noise') in the radioimmunoassay due to changes in gonadotrophin subunit activity or other immunoreactive materials. From October until February, the high amplitude LH peak frequency was consistently below 1 peak per $3 \mathrm{~h}$ and prolactin concentrations in plasma consistently above $50 \mathrm{ng} / \mathrm{ml}$. During this time, the number of antral follicles ( $\geqslant 1 \mathrm{~mm}$ diam.) was above 35 per ewe and the proportion of healthy follicles uniformly higher than in most other months of the year. Moreover, the healthy follicles during anoestrus contained similar levels of granulosa-cell aromatase activity as did follicles from the breeding season when the appropriate quantities of testosterone were made available. Two questions arise from these findings of a high level of follicular activity during anoestrus: (1) why do oestrogen-enriched follicles (i.e. with follicular fluid oestradiol $\geqslant 90 \mathrm{ng} / \mathrm{ml}$ ) not develop and (2) why does ovulation not occur? One possibility is that the frequency of highamplitude LH discharges is too low to sustain an adequate supply of thecal androgen substrate for the synthesis of oestradiol (see McNatty, 1982, for review). This hypothesis is also supported by the finding that the administration of exogenous LH to anoestrous ewes at a frequency of one injection per $2 \mathrm{~h}$ is able to induce ovulation and cyclic progestational activity (McNatty et al., 1983b).

An important time of the year with respect to seasonal changes in FSH secretion appeared to be the months of October, November and December, when there is a greater antral follicular activity relative to that during the previous 6 months. Although this increased output of FSH varied markedly between animals, it coincided with the reduction in high-amplitude LH peak frequency and the entry of animals into a state of hyperprolactinaemia. Whilst the timing of this FSH rise is of interest, the role of FSH on antrum formation, and follicular maturation in sheep, remains to be elucidated (Carson, Findlay, Burger \& Trounson, 1979; McNatty, 1982). 
In conclusion, the present studies show that the level of antral follicular activity changes throughout the year in synchrony with the circannual patterns of prolactin secretion and daylength. Moreover, these data support the notion that anovulation during seasonal anoestrus is due to a reduced frequency of high amplitude LH peaks in plasma.

We thank the National Pituitary Agency, Maryland, U.S.A., for the generous supply of pituitary hormones; Dr L. Reichert Jr, Albany Medical College of Union University, Albany, NY, U.S.A. for the ovine prolactin preparation LER-860-2; Dr J. R. McNeilly, Stow, Scotland, for the prolactin antiserum, Dr W. Butt, Birmingham, U.K., for the rabbit antisera against human FSH (M-94); and Dr H. Papkoff, University of California, San Francisco, U.S.A. for the FSH preparation G4-150C; Miss L. Morrison and Mrs K. Mason for statistical advice; Mr P. Smith, Mrs J. Fannin and Mrs L. Kieboom for assistance with blood sampling; and Mr L. Freeman and the Wallaceville Farm Staff for assistance in animal management.

\section{References}

Arendt, J., Symons, A.M. \& Laud, C. (1981) Pineal function and photoperiod in the ewe. In Photoperiodism and Reproduction in Vertebrates, pp. 219-229. Eds R. Ortavant, J. Pelletier \& J.-P. Ravault. I.N.R.A., Versailles.

Baird, D.T., Baker, T.G., McNatty, K.P. \& Neal, P. (1975) Relationship between the secretion of the corpus luteum and the length of the follicular phase in the ovarian cycle. J. Reprod. Fert. 45, 611-619.

Cahill, L.P. (1979) Studies of folliculogenesis in the sheep. Ph.D. thesis, L'Université Paris VI.

Carson, R.S., Findlay, J.K., Burger, H.E. \& Trounson, A.O. (1979) Gonadotropin receptors of the ovine ovarian follicle during follicular growth and atresia. Biol. Reprod. 21, 75-89.

Cole, H.H. \& Miller, R.J. (1935) Changes in the reproductive organs of the ewe with some data bearing on their control. Am. J. Anat. 57, 39-87.

Jackson, G.L. \& Davis, S.L. (1979) Comparison of luteinizing hormone and prolactin levels in cycling and anestrous ewes. Neuroendocrinology 28, 256263.

Kammlade, W.G., Jr, Welch, J.A., Nalbandov, A.V. \& Norton, H.W. (1952) Pituitary activity of the sheep in relation to the breeding season. J. Anim. Sci. 11, 646655 .

Karsch, F.J., Bittman, E.L. \& Legan, S.J. (1981) Importance of retinal photoreceptors and the pineal gland to the photoperiodic control of seasonal breeding in the ewe. In Photoperiodism and Reproduction in Vertebrates, pp. 213-218. Eds R. Ortavant, J. Pelletier \& J.-P. Ravault. I.N.R.A., Versailles.

Lamming, G.E., Moseley, S.R. \& McNeilly, J.R. (1974) Prolactin release in sheep. J. Reprod. Fert. 40, 151 168.

Legan, S.J., Karsch, F.J. \& Foster, D.L. (1977) The endocrine control of seasonal reproductive function in the ewe: a marked change in response to the negative feedback action of estradiol on luteinizing hormone secretion. Endocrinology 101, 818-824.

Lincoln, G.A. \& Short, R.V. (1980) Seasonal breeding: Nature's contraceptive. Recent Prog. Horm. Res. 36, $1-52$.
Martensz, N.D., Baird, D.T., Scaramuzzi, R.J. \& Van Look, P.F.A. (1976) Androstenedione and the control of luteinizing hormone in the ewe during anoestrus. $J$. Endocr. 69, 227-237.

McIntosh, R.P. \& McIntosh, J.E.A. (1982) Luteinizing hormone release from sheep pituitary cells in vitro in response to a variety of applied pulse trains of gonadotrophin releasing hormone. Proc. Aust. Endocr. Sco. 25, 39, Abstr.

McNatty, K.P. (1982) Ovarian follicular development from the onset of luteal regression in humans and sheep. In Follicular Maturation and Ovulation, pp. 119. Eds R. Rolland, E. V. van Hall, S. G. Hillier, K. P. McNatty \& J. Schoemaker. Excerpta Medica, Amsterdam.

McNatty, K.P., Moore-Smith, D.M., Makris, A., Osathanondh, R. \& Ryan, K.J. (1979) The microenvironment of the human antral follicle: interrelationships among the steroid levels in antral fluid, the population of granulosa cells and the status of the oocyte in vivo and in vitro. J. clin. Endocr. Metab. 49, 687-699.

McNatty, K.P., Gibb, M., Dobson, C., Thurley, D.C. \& Findlay, J.K. (1981a) Changes in the concentrations of gonadotrophic and steroidal hormones in the antral fluid of the sheep. Aust. J. biol. Sci. 34, 67-80.

McNatty, K.P., Gibb, M., Dobson, C. \& Thurley, D.C. (1981b) Evidence that changes in luteinizing hormone secretion regulate the growth of the preovulatory follicle in the ewe. J. Endocr. 90, 375389.

McNatty, K.P., Ball, K., Gibb, M., Hudson, N. \& Thurley, D.C. (1982a) Induction of cyclic ovarian activity in seasonally anoestrous ewes with exogenous GnRH. J. Reprod. Fert. 64, 93-96.

McNatty, K.P., Gibb, M., Dobson, C., Ball, K., Coster, J., Heath, D. \& Thurley, D.C. (1982b) Preovulatory follicular development in sheep treated with PMSG and/or prostaglandin. J. Reprod. Fert. 65, 111-123.

McNatty, K.P., Hillier, S.G., van den Boogaard, A.M.J., Trimbos-Kemper, J.C.M., Reichert, L.E., Jr \& van Hall, E.V. (1983a) Follicular development during the luteal phase of the human menstrual cycle. J. clin. Endocr. Metab. 56, 1022-1032. 
McNatty, K.P., Hudson, N., Gibb, M., Ball, K., Fannin, J., Kieboom, L. \& Thurley, D.C. (1983b) Effects of long-term treatment with $\mathrm{LH}$ on induction of cyclical ovarian activity in seasonally anoestrous ewes. $J$. Endocr. (in press).

Merriam, G.R. \& Wachter, K.W. (1982) Algorithms for the study of episodic hormone secretion. $A m . J$. Physiol. 243, E310-E318.

Munro, C.J., McNatty, K.P. \& Renshaw, L. (1980) Circaannual rhythms of prolactin secretion in ewes and the effect of pinealectomy. $J$. Endocr. 84, 83-89.

Salamonsen, L., Jonas, H.H., Burger, G.C., Buckmaster, J.M., Chamley, W.A., Cumming, I.A., Findlay, J.K. \& Goding, J.R. (1973) A heterologous radioimmunoassay for follicle-stimulating hormone: application to measurement of FSH in the ovine estrous cycle and in several other species including man. Endocrinology 93, 610-618.

Scaramuzzi, R.J. \& Baird, D.T. (1977) Pulsatile release of luteinizing hormone and the secretion of ovarian steroids in sheep during anestrus. Endocrinology 101, 1801-1806.

Van Look, P.F.A. (1976) Studies on the pathophysiology of gynaecological endocrine disorders. Ph.D. thesis, University of Edinburgh.

Walton, J.S., McNeilly, J.R., McNeilly, A.S. \& Cunningham, F.J. (1977) Changes in concentrations of follicle-stimulating hormone, luteinizing hormone, prolactin and progesterone in the plasma of ewes during the transition from anoestrus to breeding activity. J. Endocr. 75, 127-136.

Received 22 June 1983 